\title{
The Relationship Between Product Quality and Brand Image with Willingness to Buy: A Study on Batik Lasem Consumer
}

\author{
Kristiana Haryanti ${ }^{1 *}$, Theresia Dwi Hastuti ${ }^{2}$, Andreas Lako $^{2}$, and Krisprantono ${ }^{3}$ \\ ${ }^{1}$ Psychology Faculty, Soegijapranata Catholic University, Central Java, Indonesia \\ ${ }^{2}$ Economics and Business Faculty, Soegijapranata Catholic University, Central Java, Indonesia \\ ${ }^{3}$ Architecture and Design Faculty, Soegijapranata Catholic Uiniversity, Central Java, Indonesia
}

\begin{tabular}{|c|c|}
\hline ARTICLE INFO & ABSTRACT \\
\hline $\begin{array}{l}\text { Keywords: } \\
\text { Product Quality } \\
\text { Brand Image } \\
\text { Willingness to Buy } \\
\text { Batik Lasem }\end{array}$ & $\begin{array}{l}\text { This research is important because there are still many batik craftsmen } \\
\text { unconsciousness of the importance of product quality and brand image in } \\
\text { influencing the possibility of consumers buying products (batik Lasem } \\
\text { cloth). Batik Lasem is a traditional Indonesian cloth originating from the } \\
\text { City of Lasem in Central Java, Indonesia. The purpose of this research is } \\
\text { to empirically examine product quality concepts consisting of eight (8) } \\
\text { dimensions (performance, reliability, features, suitability, durability, } \\
\text { service capability, aesthetics, and quality of customer perception) and } \\
\text { brand image with a willingness to buy. The data collection was done } \\
\text { involving } 181 \text { Lasem batik buyers in Central Java, Indonesia. Data were } \\
\text { analyzed using SPSS version } 20 \text {. Three (3) hypotheses in this study were } \\
\text { accepted. The result of the analysis shows that 1). There is a positive } \\
\text { significant relationship between product quality and willingness to buy; } \\
\text { 2) There is a positive significant relationship between brand image and } \\
\text { willingness to buy, and 3). There is a significant relationship between } \\
\text { product quality and brand image with willingness to buy. }\end{array}$ \\
\hline
\end{tabular}

\section{Introduction}

Batik is an original intangible cultural heritage of Indonesia that was recognized by UNESCO in 2009, precisely on October 2 (Rachmawati \& Sawitri, 2015). According to Iwan Tirta (Kanti, 2008) batik is a traditional technique for decorating cloth by drawing certain motifs/patterns that contain philosophical meaning by using canting (a tool for drawing) and candles. The word batik comes from a combination of two Javanese words, amba, which means "writing" and titik which means "point" (Rachmawati \& Sawitri, 2015).

To preserve and maintain batik cloth so that it does not become extinct, the government, through the Regulation of Minister of Home Affairs of the Republic of Indonesia (Permendagri) No. 6 2016, instructs that Civil Servants, especially in Java, are required to wear batik cloth as the official clothing on every Friday. This government policy increases sales of batik significantly in the regions producing batik. Therefore, there is a need to develop batik business through micro, small, and medium business (UMKM) and this should be supported by all parties, i.e. the government, private and even universities through research. This support, in which research is one of them, is useful for the development of batik businesses (this research is one of them).

The government has made efforts to develop Batik through regulations and decisions. Despite the increasing use of batik in the community, however, there are still many Batik craftsmen/producers who do not have the awareness to improve the quality and the brand image of batik that they produce. They seem to be complacent because they feel that they already get

* Correspondence concerning this article should be addressed to Kristiana Haryanti, Organizational Pyschology Department, Soegijapranata Cathoilic University. Email: kristiana@unika.ac.id 
the benefit because of the regulations made by the government which "force" the civil servants to wear Batik as one of the work uniforms. Batik craftsmen/producers should have an awareness of the importance of marketing strategies by knowing the reasons why consumers buy batik and these include the quality of batik products and brand image.

When we study consumer behavior, we will learn how individuals choose, buy, and use the product (Kotler and Keller (2007). A product is said to be successfully marketed when it is accepted and bought by consumers. Willingness to buy is the intention of behavior of consumers to buy (Jahangir, Parvez, and Bhattacharjee, 2009). In making a purchase, consumers have considerations before buying. There are values contained in the product that influence and cause someone to decide to buy. Zeinthaml (1988) stated that there are two product qualities, namely intrisic and extrinsic. Intrinsic quality is related to the signs of a product, such as color and texture. Meanwhile, extrinsic quality is a sign of quality outside the product, for example brand image. The evidence in the field shows that each consumer has different considerations (Beneke, et all, 2013) and it is interesting to be studied.

Tjiptono (2012) stated one product marketing strategy is to have a competitive advantage by paying attention to the brand so that it can be a special characteristic/differentiator of a product. According to Low and Lamb (2000), research interest in branding continues to be strong in the marketing literature and it has been much discussed in the marketing literature.

Other than a well-known brand, product quality is one of the considerations of consumers when deciding to buy a product. Product quality is the overall quality or excellence of a product related to what is expected by consumers. According to Kotler and Keller (2007), quality is the totality of features and characteristics that enable products to satisfy the needs of consumers both stated and not stated. A product that has good quality will certainly make consumers interested in buying it again in the future. A pleasant experience that is marked by the quality of goods that matches or exceeds expectations (satisfaction with the product) will make consumers to repurchase the product. Good product quality will make consumers feel satisfied (Lasander, 2013). If the product has a marker (brand) that is known or recorded in consumers' memory, it will make consumers purchase it if they need the item in the future.

Jahangir, et al. (2009) stated there is a significant relationship between product quality and brand image with consumers' desire to buy. Beneke, et al. (2013) also suggested that product quality has a significant effect on consumers' desire to buy a product. Based on the results of the above studies, the researchers are interested in conducting research whether the quality of product and brand image are significantly related to the desire to buy. Given that the product to be studied is Batik Lasem, this research question needs to be proven empirically.

This research is based on the efforts of researchers to help develop micro, small and medium businesses in Indonesia, especially in the city of Lasem, Central Java, because batik Lasem has become one of the most potential businesses to improve the lives of the local people and support the Indonesian economy. The purposes of this study are:

1. To empirically examine the relationship between product quality and willingness to buy.

2. To empirically examine the relationship between brand image and willingness to buy.

3. To empirically examine the relationship between product quality and brand image with willingness to buy.

The results of this study will be able to provide benefits and feedback to batik Lasem craftsmen/producers so that they can further develop their business. This research is also expected to provide feedback to the government to preserve batik.

\section{Literature Review and Hypotheses}

2.1. Product quality and willingness to buy

In buying an item, consumers will certainly pay attention and consider the product, whether the product meets the qualifications it needs. Products are objects that can be tangible or 
intangible which someone can purchase. Furthermore, according to Kotler and Armstrong (2008), a product is a set of characteristics of goods and services that has the ability to meet the needs which is a combination of durability, reliability, accuracy, service capability as well as other attributes of a product. Another expert, Garvin (2007), stated that producet quality is a collection of features and sharp brand product characteristics which have a contribution to the ability to fulfill the specified demand.

Gaspersz (2008) explains that there are eight (8) dimensions of the quality of a product:1). Performance, namely the core characteristics of a product. This can be defined as the appearance of a real product. Product appearance is a reflection of how a product is presented or displayed to customers; 2). Reliability, namely the consistency of the reliability of a product in the operational process in the eyes of consumers. The reliability of a product is also a measure of the likelihood that a product will not be damaged or fail in a certain period of time. A product is said to have high reliability when it can attract the trust of consumers regarding the quality of reliability of a product; 3 ). Features, namely the secondary or complementary characteristics, can be defined as the level of completeness of the attributes that exist in a product or the existence of additional privileges. At a certain point, the performance of each brand is almost the same but the difference lies in its features; 4). Conformance to specifications, i.e. the extent to which the design characteristics and operation meet predetermined standards. This can be defined as the rate at which all units produced are identical and meet the promised target specifications; 5). Durability, i.e. how long the product can continue to be used. A product is expected not to be broken even though it is often used, and it is also expected to be able to function well for a long time; 6). Service capabilities; they include speed, competence, comfort, easy repair, and satisfying complaint handling. They can also be defined as a measurement of how easy it is to repair a damaged or failed product; 7). Aesthethics, namely the beauty of a product that can be captured by the five senses and can be defined as attributes attached to a product, such as color, model or design, shape, taste, scent and others; 8). Customer perceived quality, namely the quality that the customer feels. When applied to measuring product quality, Perceived Quality is the basic quality of the product.

Kotler and Keller (Hermawan, 2011) stated that product quality must be measured through the perception of product quality that buyers feel. Consumer perceptions of product quality are attitudes of customers because they have compared expectations with the reality of the product (Zeithaml, 1988). If consumers feel that product quality can meet their expectations, they will have the desire to make purchases again. Other researchers, Grewal, et al 1999) also said that product quality is a significant determinant of purchasing. This opinion is also supported by Cronin et al (2000) and Snojt et al (2004) who stated that when consumers feel that the quality of product is higher than they expect, this will cause a desire to buy. Furthermore, Agarwal and Teas (2004) suggested that customers will use (buy) a product when the product is in accordance with the product quality standards they expect.

\section{H1. There is a positive significant relationship between product quality and willingness to buy}

\subsection{Brand Image and willingness to buy}

Brand is one of the important things in the production process. Brands can be perceived as the life of a product (Rahmawati and Sawitri, 2015). It has an important role in the sale of products or services. According to Kotler (2000), a brand is a name, term, symbol, design that is used to differentiate one's products and services from those of the competitors. Brand names are important in consumer's evaluations of brands. Brand names help consumers remember the benefits of the brand (Janiszewski and van Osselaer, 2000).

Furthermore, according to Kotler (2000), image is a way of how people perceive a product. Image is influenced by many factors outside the control of the producer. Consumers develop 
set of beliefs toward brand through the attributes of the product/service they receive. A set of beliefs about a brand forms a brand image. Consumers' brand image of a product will vary according to the experience they receive. Another expert, Keller (1993), defines brand image as an association or perception made by consumers based on their memories of a product. Thus, the brand image does not exist in the actual technology, features, or products themselves, but it is something that is brought about by promotions, advertisements, or consumers who use the product. Through the brand image, consumers can recognize a product, evaluate quality, reduce purchase risk, gain experience and certain satisfaction from certain branded products that they buy.

High quality brands enable consumers to identify the advantages and specificities of a brand that leads to loyalty to the brand (David, 1991; Oliver, 1997). This means that the brand will make consumers return to buy it. Furthermore, Hsieh and Li (2008) stated that a good brand will give a strong message effect when compared with competitors' brand information. A good brand name and a buying experience that do not disappoint will make consumers remember and have a perception of good quality of the product. This situation will be able to stimulate a strong consumers' urge to buy products with the same brand. This means that brand image is an important determinant in making decisions for the consumers to buy (Burmann et al, 2015). According to Akaah and Korgaonkar (1988), consumers are more likely to buy famous brand products with positive brand image as a way to reduce purchasing risk. This opinion is supported by Grewal, et all (1998), who stated that the better the brand image, the more consumer recognition of the quality of its products. Consumers usually have limitations in terms of the amount of time and product knowledge they have. Therefore, to make a purchasing decision they will tend to choose products with a brand image that is already known. This argument is supported by Rao and Monroe (1988) who stated that a brand with a more positive image does have the effect of reducing the risk of bad perception of the product to consumers and increasing positive feedback from consumers. Therefore, consumers generally reduce the risk of purchasing and believe that they can make satisfying purchases by choosing well-known brands.

\section{H2. There is a positive significant relationship between brand image and willingness to buy}

\subsection{Product quality and brand image with willingness to buy}

The desire to buy means the subjective tendency of consumers to buy certain products, and it has proven to be a key factor in predicting consumer behavior (Fishbein and Ajzen, 1975). According to Jahangir, Parvez, and Bhattacharjee (2009), willingness to buy consists of the possibility of customers to shop and buy products. In buying products, consumers may be able to respond differently to the same product (Lampe \& Gazda, 1995).

There are several considerations made by consumers before buying a product. Akaah (1988) suggested that consumers are more likely to buy famous brand products with a positive brand image as a way to reduce purchasing risk. Therefore, consumers generally believe that they can make satisfying purchases by choosing well-known brands and also reduce the risk of purchasing by doing so (Gul, et all, 2012). Furthermore, Cronin et al. (2000) said that highly perceived quality of a product will increase the perceived value of the product which ultimately results in consumers' willingness to buy. Snoj et al. (2004) also stated the same thing, that is, the perceived product quality will make consumers have the desire to buy. Research conducted by Jahangir, et al (2009) also shows a significant relationship between product quality and brand image with the desire to buy.

H3. There is a significant relationship between product quality and brand image with willingness to buy 


\subsection{Conceptual framework}

Based on the objectives and literature previously explained, this study proposes a model to empirically prove whether there is a relationship between product quality and brand image with willingness to buy. This research model is shown in Figure 1.

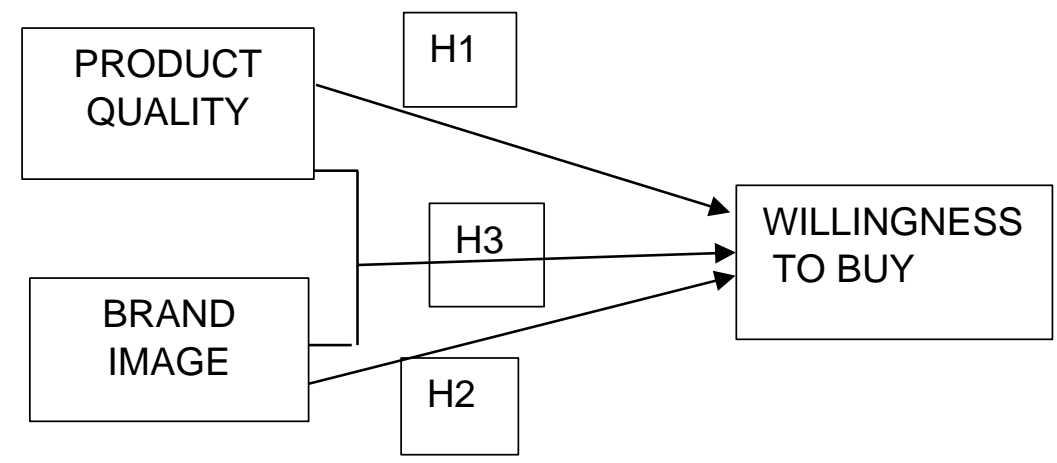

Figure 1. Conceptual framework of research variable and their relationships

\section{Research Methods}

The research method used in this study is a quantitative analysis method, namely research that emphasizes its analysis on numerical data or numbers obtained by statistical methods (Sugiyono, 2010).

\subsection{Research Variables}

The variables of this study consist of 2 (two) independent variables namely product quality $\left(\mathrm{X}_{1}\right)$ and brand image $\left(\mathrm{X}_{2}\right)$ and one (1) dependent variable, namely willingness to buy (Y).

\subsection{Population and sample}

Population is defined as a region of realizations consisting of objects/subjects that have certain qualities and characteristics determined by researchers to be studied and then the conclusions are drawn (Sugiyono, 2006). The population used in this study are Lasem batik consumers who shop for batik in the city of Lasem, Central Java, Indonesia.

Samples are part of the population. The samples in this research were taken using certain procedures so that only a portion of the population was taken and used to determine the desired traits and characteristics in the population (Nazir, 2005). The sampling technique used in this study was incidental sampling. The samples in this study, as many as 181 respondents, were consumers who bought batik Lasem in 19 batik Lasem craftsman shops in Lasem city, Central Java, Indonesia.

\subsection{Method of Data Collection and Measurement}

Data collection techniques used in this study are quantitative methods using a scale that is distributed to respondents. Scale according to Nazir (2005) is a way to change qualitative data (attributes) into a quantitative order (variables). The measurement scale used in this study is a Likert scale. Likert scale is related to statements about one's attitude on a matter (Umar, 2005). On a scale there are no right or wrong answers. Subjects were asked to choose one alternative answer from the five choices of answers provided, namely from strongly disagree (score 1) to strongly agree (score 5).

There are three (3) scales used to measure the research variables, namely: 1) Product quality scale proposed by Gaspersz (2008) which consists of 8 (eight) dimensions: performance, 
reliability, features, conformance, durability, service ability, aesthetics, and customer perceived quality. Each dimension consists of 3 (three) items; 2) Brand image scale, adapted from a scale created by Low and Lamb (2000), which consists of 6 (six) items; and 3) Willingness to buy scale adapted from a scale made by Dodd et all (Sweeney et all,1999) which consists of 2 (two) items.

\section{Results}

Information about the description of respondents in this study can be seen in Table 1 .

Table 1.

Sample Characteristics in Summary

\begin{tabular}{llccllcc}
\hline Variable & Type & Frek & $\begin{array}{c}\text { Percentage } \\
(\mathbf{\%})\end{array}$ & Variable & Type & Frek & $\begin{array}{c}\text { Percentage } \\
(\mathbf{\%})\end{array}$ \\
\hline Sex & Man & 69 & 38.1 & Education & Basic school & 10 & 5.5 \\
& Woman & 101 & 55.8 & & Junior High School & 28 & 15.5 \\
& Missing & 11 & 6.1 & & Senior High School & 68 & 37.6 \\
Age & $<28$ & 51 & 28.2 & & Vocational School & 15 & 8.3 \\
& $29-40$ & 81 & 44.8 & & Diploma & 4 & 2.2 \\
& $41-52$ & 41 & 22.7 & & Under Graduate & 51 & 28.2 \\
& $53-64$ & 7 & 3.9 & & Magister & 5 & 2.8 \\
& $>65$ & 1 & 0.6 & & & & \\
\hline
\end{tabular}

Source: processed primary data

From 181 respondents, the number of female Batik cloth buyers is higher than that of male. The number of male buyers is $69(38.1 \%)$ and the number of female buyers is 101 people (55.8\%), and there are 11 people $(6.1 \%)$ who do not reveal their sex. In terms of age, the largest number of respondents is in the age range of 29 to 40 years with a total of 81 people $(44.8 \%)$. In terms of the education of respondents, most of them were high school graduates, i.e. 68 people $(37.6 \%)$.

In this study, the alpha coefficient can be seen in Table 2. The table shows that the three variables are between 0.854 and 0.964 . According to Nunally (1978), reliability is in the range of 0.60 to 0.80 . Therefore, the scale of the 3 (three) variables used in this study is reliable.

Table 2.

Variable, Cronbach Alpha and Number of Items

\begin{tabular}{lcc}
\hline Variable & Cronbach Alpha & Number of Items \\
Product Quality & 0.964 & 24 \\
Brand Image & 0.859 & 6 \\
Willingness to Buy & 0.854 & 2 \\
\hline
\end{tabular}

Source: processed primary data

\subsection{Correlation Analysis}

Correlation analysis is carried out to find out the correlation between variables. The two variables, namely product quality and brand image, have a positive significant correlation. Product quality is positive significantly correlated with willingness to buy $(r=0.685, p<0.01)$. Likewise, brand image also has a positive significant correlation with willingness to buy $(\mathrm{r}=$ $0.808, \mathrm{p}<0.1)$. The correlation analysis results also show a positive significant relationship between product quality and brand image $(r=0.808, \mathrm{p}<0.1)$.

\subsection{Regression Analysis}


To test hypothesis 3, a regression analysis and partial correlation were performed. Table 4 contains the results of the regression analysis. From the results it can be seen that $F=98.509$, $\mathrm{p}<0.01$. It means there is a relationship between product quality and brand Image with willingness to buy. Hypothesis 3 is proven acceptable.

Table 4.

Regression Analysis Model Summary

\begin{tabular}{|c|c|c|c|c|c|c|c|c|c|}
\hline \multirow[b]{2}{*}{ Model } & \multirow[b]{2}{*}{$\mathrm{R}$} & \multirow[b]{2}{*}{ R Square } & \multirow[b]{2}{*}{$\begin{array}{l}\text { Adjusted R } \\
\text { Square }\end{array}$} & \multirow[b]{2}{*}{$\begin{array}{l}\text { Std. Error of } \\
\text { the Estimate }\end{array}$} & \multicolumn{5}{|c|}{ Change Statistics } \\
\hline & & & & & $\begin{array}{c}\text { R Square } \\
\text { Change }\end{array}$ & F Change & df1 & $\mathrm{df} 2$ & $\begin{array}{c}\text { Sig. F } \\
\text { Change }\end{array}$ \\
\hline 1 & $.726^{\mathrm{a}}$ & .527 & .521 & .819 & .527 & 98.509 & 2 & 177 & .000 \\
\hline
\end{tabular}

a. Predictors: (Constant), Total Brand Image, Total Product Quality

Source: processed primary data

The effective contribution of the product quality and brand image variables to willingness to buy is $52.7 \%$ so that there are still $47.3 \%$ other variables outside the research that affect willingness to buy. After calculating in more detail to determine the contribution of product quality and brand image, the researchers found that the effective contribution of product quality to willingness to buy is $24.5 \%$. The effective contribution of brand image to willingness to buy is $28.2 \%$.

Furthermore, to test hypothesis 1 and hypothesis 2, a partial correlation analysis was performed. The results can be seen in Table 5. The analysis shows that there is a positive significant correlation between product quality with willingness to buy by controlling brand image $\left(\mathrm{ry}_{1.2}=0.358, \mathrm{p}<0.1\right)$. This means Hypothesis 1 is proven acceptable. The partial correlation results also show that there is a positive significant correlation between brand image and willingness to buy by controlling product quality (ry2.1 $=0.405, \mathrm{p}<0.1$ ). These results indicate that hypothesis 2 is also proven.

Table 5

Partial Correlation Aanalysis

Coefficients $^{\mathrm{a}}$

\begin{tabular}{|c|c|c|c|c|c|c|c|c|c|c|}
\hline \multirow{2}{*}{\multicolumn{2}{|c|}{ Model }} & & \multicolumn{2}{|c|}{$\begin{array}{c}\text { Unstandardized } \\
\text { Coefficients } \\
\end{array}$} & \multirow{2}{*}{$\begin{array}{c}\begin{array}{c}\text { Standardized } \\
\text { Coefficients }\end{array} \\
\text { Beta } \\
\end{array}$} & \multirow[t]{2}{*}{$\mathrm{t}$} & \multirow[t]{2}{*}{ Sig. } & \multicolumn{3}{|c|}{ Correlations } \\
\hline & & & B & Std. Error & & & & Zero-order & Partial & Part \\
\hline & (Constant) & & 1.083 & .576 & & 1.879 & .062 & & & \\
\hline & $\begin{array}{l}\text { Total } \\
\text { Quality }\end{array}$ & & .036 & .009 & .358 & 4.080 & .000 & .685 & .293 & .211 \\
\hline & Total Branc & Image & .151 & .033 & .405 & 4.624 & .000 & .694 & .328 & .239 \\
\hline
\end{tabular}

a. Dependent Variable: Total Willingness to buy

Source: processed primary data

\section{Discussion}

The main objective of this research is to empirically examine the relationship between product quality and brand image with willingness to buy among batik Lasem consumers. The results show that there is a significant relationship between product quality and brand image with willingness to buy ( $\mathrm{F}=98.509, \mathrm{p}<0.01)$. Therefore, $3^{\text {rd }}$ hypothesis is accepted.

Further analysis carried out in more detail shows that there is a positive significant relationship between product quality and willingness to buy by controlling brand image (ry $1.2=0.358$, $\mathrm{p}<0.1)$. The results of this study also show that $1^{\text {st }}$ hypothesis is accepted. Product quality has a significant correlation with willingness to buy. This means that batik consumers always consider the quality of batik products before deciding to buy them. The results of this study are 
also supported by Jahangir et al. (2009). They conducted research to buy a computer with the brand "X" among students and they found a significant correlation between product quality with willingness to buy of $0.51, \mathrm{p}<0.5$. Munir, et all (2017) stated that product quality is a strong predictor for consumers to be willing to buy a product.

The results of the analysis to test the relationship between brand image and willingness to buy by controlling product quality is proven positive significant (ry2.1 $=0.405, \mathrm{p}<0.1)$. Therefore, $2^{\text {nd }}$ hypothesis is also proven. Jahangir, et al. (2009) also found a correlation between brand image and willingness to buy. Mostafa (2018) also found that a brand that is perceived positively will make consumers want to buy. Anselmsson et al. (2014) and Munir, et all (2017) also suggested that brand image is a determinant of consumers' willingness to buy. Consumers will be more motivated to buy product brands that are unique in form and function.

Further analysis to determine the correlation between willingness to buy with eight (8) dimensions in product quality are: performance $(\mathrm{r}=0.602)$, reliability $(\mathrm{r}=0.554)$, features $(\mathrm{r}=$ $0.543)$, conformance $(\mathrm{r}=0.570)$, durability $(\mathrm{r}=0.651)$, service ability $(0.652)$, aesthetics (0.531) and customer perceived quality $(\mathrm{r}=0.604)$. Next, to find out how the respondents' response is actually related to Batik Lasem, an analysis is carried out by categorizing (excellent, good, sufficient, bad, very bad) based on the empirical mean and standard deviation. In the analysis of product quality data, it was found that the majority (44.8\%) states that Batik Lasem product quality has good criteria. $25.4 \%$ of respondents say it is good enough, $22.1 \%$ say it is bad and $7.2 \%$ say it is very bad. Not a single respondent says that the quality of Batik Lasem is very good. The same analysis is also performed on brand image data. The results show that no one says that Batik Lasem brand image is very good. There are $48.1 \%$ of respondents who say that the brand image is good. As many as $22.7 \%$ of respondents say it is good enough, $25.4 \%$ say it is bad and $3.9 \%$ say it is very bad.

\section{Conclusion and Recommendation}

Based on the results of the analysis and discussion stated above, the conclusions obtained from this study are:

1. Hypothesis 1 in this study proved that there was a positive significant relationship between product quality and willingness to buy

2. Hypothesis 2 in this study is proven, there is a positive significant relationship between brand image and willingness to buy

3. Hypothesis 3 in this study is proven, there is a positive significant relationship between product quality and brand image with willingness to buy

The researchers gives several suggestions as follows:

\subsection{For Batik Craftsmen}

They need to improve the quality of batik Lasem products and pay more attention to the brand image of batik products they make because based on the results of analysis it is shown that there is a significant relationship between product quality and brand image with consumers' willingness to buy. In addition, evidence is also found that there are no consumers who give very good ratings on the quality of batik Lasem products and the brand image used by batik Lasem craftsmen. The dimensions of product quality that needs to be given more attention are on service ability, customer perceived quality, and performance. These three dimensions have the highest correlation in relation to willingness to buy.

\subsection{For the Government}

Based on the results of this study it is not enough for the government to issue regulations governing the use of batik cloth in the organizational environment as office uniforms and 
makes it easy to provide business loan funds for craftsmen, but it is also advisable that the government provide training related to how to improve the quality of batik Lasem products. In addition, training also needs to be given on the importance of brand imaging for the business development of batik Lasem craftsmen.

\section{Acknowledgment}

This paper is the output of research that received funding from the Ministry of Research, Technology and Higher Education of the Republic of Indonesia (abbreviated RI Ministry of Research and Technology). This funding is given to increase the research interest and scientific work of lecturers as one of the three responsibilities of higher education

\section{Reference}

Agarwal, S., and Teas, R.K. (2001). Perceived value: mediating role of perceived risk. Journal of Marketing Theory \& Practice, Vol 9 (4), pp.1 - 14. https://doi.org/10.1080/10696679. 2001.11501899

Akaah, 1. P. and P. K. Korgaonkar. (1988). A Conjoint Investigation of the Relative Importance of Risk Relievers in Direct Marketing. Journal of Advertising Research 28 (4), 38-44

Anselmsson, J., Vestman, B.N., \& Johansson, U. (2014). Brand Image and customers' willingness to pay a price premium for food brands. Journal of Product \& Brand Management, Vol 23 (2), pp. 90-102. https://doi.org/10.1108/JPBM-10-2013-0414

Beneke, J., Flynn, R., Greig, T., Mukaiwa, M. (2013). The influence of perceived product quality, relative price and risk on customer value and willingness to buy: a study of private label merchandise. Journal of Product \& Brand Management. Vol. 22 (3), pp. 218-228. https://doi.org/10.1108/JPBM-02-2013-0262

Burmann, C., Schaefer, K., Maloney. P. (2007). Industri image: Its impact on the brand imageof potential employees. Journal of Brand Management, 15 (3), pp. 157 - 176. https://doi.org/10.1057/palgrave.bm.2550112

Cronin, JJ., Brady, MK., and HUlt, GTM. (2000). Assessing the effects of quality, value, and cutomer satisfaction on costumer behavioral intention in service environtments. Journal of Retailing, Vol. 76 (2), pp. 193 - 218. https://doi.org/10.1016/S0022-4359(00)00028-2

David, A. A. (1991), Managing Brand Equity: Capitalizing on the Value of a Brand Name. New York: Free Press

Fishbein, M. \& Ajzen, I. (1975). Beliefs, Attitude, Intentions and Behavior: An Introduction to theory and Research. Massachusetts: Addison-Wesley

Garvin, D. (2007). Managing Quality: The Strategic and Competitive Edge. New York: Free Press

Gasperss, V. (2008). Total Quality Management. Jakarta: Gramedia Pustaka Utama

Grewal, Dhruv, Krishnan, R. B., Julie, N. and Borin, N. (1998), The Effect of Store Name, Brand Name and Price Discounts on Consumers' Evaluations and Purchase Intentions, Journal of Retailing, Vol. 74 (3), pp. 331-352. https://doi.org/10.1016/S00224359(99)80099-2

Gul, M.S., Jan, F.A., Baloch, Q.B. (2012). Brand Image and Brand Loyalty. Abasyn Journal of Social Sciences, Vol. 3 (1), pp. 55-74 
Hermawan, B. (2011). Pengaruh Kualitas Produk terhadap kepuasan, reputasi merk dan loyalitas konsumen Jamu Tolak Angin PT. Sido Muncul. Jurnal Manajemen Teori dan Terapan, Tahun 4 (2), Agustus, pp. 9-17

Jahangir, N., Parves, N., Bhattacharjee, D. (2009). Determinants of Customers' Willingness to Buy: An Empirical Investigation. ABAC Journal. Vol. 29 (3) (September - Desember), pp. 29-37

Janiszewski, C., and Osselaer, S.M.J. (2000). A Connectionist model of Band-Quality Association. Journal of Marketing Research. Vol XXXVII, August, pp. 331-350. https://doi.org/10.1509/jmkr.37.3.331.18780

Keller, K. L. (1993). Conceptualizing, Measuring, and Managing Customer Based Brand Equity. Journal of Marketing, Vol. 57(1), pp. 1-22. https://doi.org/10.1177/002224299305700101

Kotler, P. (2000). Marketing Management Analysis, Planning, Implementation, and Control. $10^{\text {th }}$ ed. Prentice-Hall Inc. New York

Kotler, P., and Keller, K.L. (2007). Manajemen Pemasaran, Edisi 12. Jakarta: PT. Indeks

Kotler, P., and Amstrong, G. (2008). Prinsip-prinsip Pemasaaran Edisi 12 Jilid 1. Jakarta: Erlangga

Lampe, M., \& Gazda, G. M. (1995). Green Marketing in Europe and the United States: an Evolving Business and Society Interface. International Business Review, Vol. 4(3), pp. 295312. https://doi.org/10.1016/0969-5931(95)00011-N

Lasander, C. (2013). Citra Merk, Kualitas Produk, dan Promosi Pengaruhnya Terhadap Kepuasan Konsumen pada makanan Tradisional. Jurnal Emba, Vol. 1 (3) September 2013, pp. 284-293

Low, GS., Lamb, CWJr. (2000). The measurement and dimensionality of Brand Associations. Journal of Product and Brand Management. Vol. 9 (6), pp. 350-370. https://doi.org/10.1108/10610420010356966

Mostafa, H.A.P. (2018). Factors affecting consumers' willingness to buy private label brands (PLBs) Applied study on hypermarkets. Spanish Journal of Marketing - ESIC, Vol. 22 (3), pp. 341-361

Munir, S., Humayon, A.A., Ahmed, M., Haider, S., \& Jehan, N. (2017). Brand Image and Customers' Willingness to Pay a Price Premium for Female's Stitched Clothing. Pakistan Journal of Commerce and Social Sciences. Vol. 11 (3), pp. 1027-1049

Nazir, M. (2005). Metode Penelitian, Jakarta: Ghalia

Nunnally, J.C. (1978). Psychometric Theory $2^{\text {nd }}$ Ed. New York: McGraw Hill

Oliver, R. L. (1997). Satisfaction: A behavioral perspective on consumer. New York: Prince Hill

Rachmawati, R; Sawitri, S. (2015). Implementasi Strategi Branding Usaha Batik dan Pengaruhnya Terhadap Perilaku Konsumen Dan Loyalitas Konsumen pada UMKM Batik Pekalongan Jawa Tengah. Teknobuga, Vol. 2 (1) - Juni, pp. 19-40

Rao, A. R. and K. B. Monroe. (1988), The Moderating Effect of Prior Knowledge on Cue Utilization in Product Evaluations. Journal of Consumer Research, Vol. 15 (2), pp. 253264. https://doi.org/10.1086/209162 
Snoj, B., Korda, AP., and Mumel, D. (2004). The relationships among perceived quality, perceived risk, and perceived product value. Journal of Product \& Brand Management, Vol. 13 (3), pp. 156-167. DOI: 10.1108/10610420410538050

Sugiono.(2010). Metode Penelitian Pendidikan Pendekatan Kuantitatif, Kualitiatif dan $R \& D$. Bandung: Alfabeta

Sugiyono. (2006). Metode Penelitian Pendidikan (Pendekatan Kuantitatif, Kualitatif dan $R \& D)$. Bandung: Penerbit Alfabeta

Sweeney, J.C., Soutar, G.N., Johnson, L.W. (1999). The Role of Perceived Risk in The QualityValue Relationship: A Study in a Retail Environtment. Journal of Retailing. Vol 75 (1), pp. 77-105. https://doi.org/10.1016/S0022-4359(99)80005-0

Tjiptono, F. (2012). Strategi Pemasaran. Malang: Bayu Media Publishing

Umar, H. (2002). Metode Penelitian Dalam Aplikasi Pemasaran. Jakarta: PT Gramedia Pustaka Utama

Zeithaml, V.A., (1988). Consumer Perceptions of price, quality, and value: a meansedd model and synthesis of evidence, Journal of Marketing, Vol. 52, July, pp. 2 - 22. https://doi.org/10.1177/002224298805200302 